\title{
In silico analysis of riboflavin carrier proteins from different Avian species
}

\begin{abstract}
A comparative in silico characterization of the Riboflavin carrier proteins (RCP) or Riboflavin binding proteins (RfBP) was carried out to analyze their physicochemical, secondary structural and functional properties. The amino acid composition of Riboflavin binding/carrier proteins were obtained from biological databases. Molecular weights of all the proteins were around 27,000kD. pI value of Cariama cristata was the highest when compared to all other proteins. The instability index of all the proteins was more than 40 showing that all of them are probably not stable. Amino acid composition of vitamin binding proteins obtained from biological databases. The composition of serine and glutamic acid was high while low concentrations of Tryptophan, valine and glycine residues were seen when compared to other amino acids. Dominance of $\alpha$-helices and random coils was observed from the secondary structural analysis of the proteins. SOSUI server analysis has shown that all the proteins are soluble in nature.
\end{abstract}

Volume 4 Issue 6 - 2016

\author{
Sireesha Radarapu,' Ramchander Merugu,' \\ Ved Prakash Upadhyay, ${ }^{2}$ Karunakar Rao \\ $\mathrm{Kudle}^{3}$ \\ 'Mahatma Gandhi University, India \\ ${ }^{2}$ Government Engineering College, India \\ ${ }^{3}$ Department of Biochemistry, Osmania University, India
}

Correspondence: Ramchander Merugu, University College of Science, Mahatma Gandhi University, Nalgonda, Telangana -508254, Email rajumerugu0I@gmail.com

Received: October 16, 2016 | Published: December 29, 2016

Keywords: RCP, in silico, physico chemical properties, secondary structure, sepharose column chromatography

\section{Introduction}

Vitamin binding proteins bind reversibly to vitamins with high affinity and receptor like specificity in serum of vertebrates..$^{1-11}$ Riboflavin carrier proteins bind to riboflavin. RCP has been purified from many species. Vitamin binding proteins bind stoichiometrically and reversibly to vitamins with high affinity and receptor like specificity. Some of them are constitutive while some others are specific to riboflavin. These proteins supply coenzyme when there is physiological need and also regulate its supply. These binding proteins are able to scavenge nutrients and protect the embryo from infection. These specific carrier proteins like Riboflavin binding proteins, Thiamin binding proteins for vitamins have been identified in normal serum in all vertebrates. ${ }^{1-4}$ Proteins binding to water soluble vitamins such as Riboflavin binding/carrier proteins, ${ }^{5-11}$ vitamin B12 binding protein ${ }^{12,13}$ and thiamin binding protein ${ }^{14,15}$ have been demonstrated in the sera, egg white and yolk of the avian eggs. Riboflavin binding protein (RfBP) is a phosphoglycoprotein, whose primary physiological function is to store riboflavin. ${ }^{16}$ This carrier protein is essential for embryonic vitamin nutrition. ${ }^{17-20}$ Sepharose column chromatography was used to purify Riboflavin binding protein (RfBP) from Hen (Gallus gallus) egg white and yolk. ${ }^{8}$ Aquila hastate Riboflavin binding protein was purified by Kudle et al. ${ }^{7}$ Emu (Dromaius novaehollandiae) Riboflavin-binding protein (RfBP) was purified from egg white by Bindu et al. ${ }^{11}$ In the present study, a computational analysis of Riboflavin carrier proteins has been done and the results are discussed.

\section{Materials and methods}

UniProtKB/Swiss-Prot was used to retrieve the complete sequences of the Riboflavin carrier proteins. The computation of various physical and chemical parameters of the Riboflavin carrier proteins (aminoacids, positive charged residues, molecular weights, pI, negative extinction coefficient, aliphatic index, GRAVY instability index) was done using ExPASy's ProtParam tool. ExPASy's ProtScale tool was used to analyse hydrophobicity and transmembrane tendency. ${ }^{21}$ SOPMA tool server was used to characterize the secondary structural features of Riboflavin carrier proteins. ${ }^{22}$ The analysis of the Riboflavin carrier proteins motifs was done with the help of Motif Scan tool. ${ }^{23}$ The SOSUI server prediction yielded the transmembrane regions of the Riboflavin carrier proteins. ${ }^{24}$

\section{Results and discussion}

Riboflavin carrier protein primary physiological function is to store riboflavin and transfer the vitamin to the embryo. ${ }^{14-20} \mathrm{RfBP}$ was isolated and purified from parrot eggs, peacock eggs. ${ }^{25,26}$ Nikhath et al., ${ }^{25}$ purified RfBP for the first time from the yolk of parrot eggs using DEAE-Sephadex ion exchange chromatography followed by gel filtration on Sephadex G-100. Riboflavin binding protein (RfBP) from peacock eggs (Pavo cristatus) was purified by Rajendar et al. ${ }^{26}$ Serum RfBP is synthesized in the liver after which complexes with riboflavin to form the holoprotein. If it is not complexed it is excreted by the kidney. The holoserum RfBP is removed from circulation by ovarian follicles and transported into the developing oocytes. Serum RfBP plays a protective role which is important in a riboflavin deficient diet. Holo-serum RfBP is transformed into holoyolk RfBP upon modification of its oligosaccharide moieties. The magnum of the oviduct synthesizes all egg white proteins and removes many proteins from the plasma as a source of its amino acid pool. After which it is catabolised with the subsequent release of riboflavin. This riboflavin is then captured by egg white RCP, synthesized by secretory cells of the magnum. The protein is conserved through evolution ${ }^{12}$ and antibodies raised against this protein are capable of curtailing pregnancy. Karande et al., ${ }^{13}$ suggested that RfBP could be used for regulating fertility. Maehash et al., ${ }^{27}$ have reported the bitter inhibitory effect of Riboflavin-binding protein and hence it can also be used for reducing bitterness of foods. In our earlier works, we have purified the riboflavin binding proteins from different eggs. 
Table I Physico chemical characteristics of riboflavin binding protein sequences

\begin{tabular}{|c|c|c|c|c|c|c|c|}
\hline Species name & $\begin{array}{l}\text { No. of amino } \\
\text { acids }\end{array}$ & $\begin{array}{l}\text { Molecular } \\
\text { weight }\end{array}$ & $\mathbf{P I}$ & $\begin{array}{l}\text { - Ve charged } \\
\text { residues }\end{array}$ & $\begin{array}{l}\text { + Ve charged } \\
\text { residues }\end{array}$ & $\begin{array}{l}\text { Extinction } \\
\text { coefficient }\end{array}$ & $\begin{array}{l}\text { Instability } \\
\text { index }\end{array}$ \\
\hline Gallus gallus & 238 & 27211.4 & 5.13 & $3.50 \mathrm{E}+0 \mathrm{I}$ & 23 & 46410 & 77.89 \\
\hline Dromaius & 238 & 27343.9 & 5.25 & 34 & 25 & 53400 & 69.78 \\
\hline Merops nubicus & 239 & 27390.7 & 5.58 & 32 & 26 & 54890 & 63.25 \\
\hline Charadrius vociferous & 238 & 27346.8 & 5.52 & 33 & 25 & 53400 & 65.92 \\
\hline Cariama cristata & 239 & 27563.2 & 7.37 & 31 & 32 & 53400 & 65.13 \\
\hline Nipponia nippon & 240 & 27494.1 & 6.69 & 31 & 30 & 53400 & 64.32 \\
\hline Coturnix japonica & 238 & 27237.4 & 5.36 & 34 & 23 & 44920 & 75.55 \\
\hline
\end{tabular}

Table 2 Amino acid composition of Riboflavin binding protein sequences

\begin{tabular}{|c|c|c|c|c|c|c|}
\hline Amino acids & Gallus gallus & Dromaius & Merops nubicus & Charadrius vociferous & Cariama cristata & Nipponia Nnippon \\
\hline Ala & 6.3 & 4.6 & 5.4 & 5 & 5 & 5 \\
\hline Arg & 3.4 & 2.5 & 2.9 & 2.1 & 3.8 & 2.5 \\
\hline Asn & 3.8 & 4.6 & 5.4 & 4.6 & 4.6 & 3.3 \\
\hline Asp & 4.6 & 3.8 & 4.6 & 4.6 & 5.4 & 4.6 \\
\hline Cys & 8 & 8 & 7.9 & 8 & 7.9 & 7.9 \\
\hline Gln & 4.6 & 3.4 & 3.8 & 3.8 & 3.8 & 3.3 \\
\hline Glu & 10.1 & 10.5 & 8.8 & 9.2 & 7.5 & 8.3 \\
\hline Gly & 2.9 & 3.4 & 3.3 & 3.4 & 2.9 & 3.8 \\
\hline His & 3.4 & 2.5 & 2.5 & 3.4 & 2.1 & 3.3 \\
\hline Ile & 3.8 & 3.4 & 2.5 & 3.4 & 3.3 & 2.9 \\
\hline Leu & 6.3 & 6.7 & 5.9 & 6.3 & 5.9 & 6.2 \\
\hline Lys & 6.3 & 8 & 7.9 & 8.4 & 9.6 & 10 \\
\hline Met & 3.4 & 3.8 & 3.3 & 3.8 & 3.8 & 3.8 \\
\hline Phe & 3.4 & 3.4 & 3.3 & 3.4 & 3.3 & 3.3 \\
\hline Pro & 3.4 & 3.4 & 3.3 & 3.4 & 3.3 & 3.3 \\
\hline Ser & 13.4 & 13 & 13 & 12.2 & 13 & 13.3 \\
\hline Thr & 4.2 & 4.2 & 4.2 & 4.6 & 4.6 & 5 \\
\hline Trp & 2.5 & 2.9 & 2.9 & 2.9 & 2.9 & 2.9 \\
\hline Tyr & 3.8 & 4.2 & 4.6 & 4.2 & 4.2 & 4.2 \\
\hline Val & 2.5 & 3.8 & 4.2 & 3.4 & 2.9 & 2.9 \\
\hline Pyl & 0 & 0 & 0 & 0 & 0 & 0 \\
\hline $\mathrm{Sec}$ & 0 & 0 & 0 & 0 & 0 & 0 \\
\hline
\end{tabular}

Table 3 Secondary structural analysis of Riboflavin binding proteins

\begin{tabular}{lllllll}
\hline Gallus gallus & & Dromaius & Merops nubicus & Charadrius vociferous & Cariama cristata & Nipponia nippon \\
\hline Alpha helix & 50 & 42.02 & 38.49 & 42.44 & 40.59 & 35.42 \\
310 helix & 0 & 0 & 0 & 0 & 0 & 0 \\
Pi helix & 0 & 0 & 0 & 0 & 0 & 0 \\
Beta bridge & 0 & 0 & 0 & 0 & 0 & 0 \\
Extended Strand & 12.18 & 12.61 & 15.48 & 14.29 & 15.9 & 13.75 \\
\hline
\end{tabular}


Table Continued....

\begin{tabular}{lllllll}
\hline Gallus gallus & & Dromaius & Merops nubicus & Charadrius vociferous & Cariama cristata & Nipponia nippon \\
\hline Beta turn & 6.3 & 6.72 & 8.79 & 7.98 & 9.21 & 7.5 \\
Bend region & 0 & 0 & 0 & 0 & 0 & 0 \\
Random coil & 31.51 & 38.66 & 37.24 & 35.29 & 34.31 & 43.33 \\
Ambiguous state & 0 & 0 & 0 & 0 & 0 & 0 \\
Other state & 0 & 0 & 0 & 0 & 0 & 0
\end{tabular}

Table 4 SOSUl server analysis of Riboflavin binding proteins

\begin{tabular}{|c|c|c|c|c|c|c|}
\hline Nature & Gallus gallus & Dromaius & Merops nubicus & Charadrius vociferous & Cariama cristata & Nipponia nippon \\
\hline Soluble/ Transmembrane & Soluble & Soluble & Soluble & Soluble & Soluble & Soluble \\
\hline
\end{tabular}

\section{Conclusion}

In this study the physicochemical properties of RCP proteins obtained from database are presented in Table 1. Negative charged aminoacids were more than positively charged aminoacids in the all the proteins compared (Table 1). Molecular weights of all the proteins were around $27,000 \mathrm{kD}$. pI value of Cariama cristata was the highest when compared to all other proteins. The instability index of all the proteins was more than 40 showing that all of them are probably not stable. Amino acid composition of vitamin binding proteins obtained from biological databases is presented in Table 2. The composition of serine and glutamic acid was high while low concentrations of Tryptophan, valine and glycine residues were seen when compared to other aminoacids. From Table 3, dominance of $\alpha$-helices and random coils was observed from the secondary structural analysis of the proteins. SOSUI server analysis Table 4 has shown that all the proteins are soluble in nature.

\section{Acknowledgements}

None.

\section{Conflict of interest}

The author declares no conflict of interest.

\section{References}

1. Kanai M, Raz A, Goodman DS. Retinol-binding protein:the transport protein for vitamin A in human plasma. J Clin Invest. 1968;47(9):20252044.

2. Thomas WC, Morgan HG, Conner TB, et al. Studies of antiricketic activity in sera from patients with disorders of calcium metabolism and preliminary observations on the mode of transport of vitamin D in human serum. J Clin Invest. 1959;38(7):1078-1085.

3. Edelstein S, Lawson DE, Kodicek E. The transporting proteins of cholecalciferol and 25-hydroxycholecalciferol in serum of chicks and other species. Partial purification and characterization of the chick proteins. Biochem J. 1973;135(3):417-426.

4. Abe T, Muto Y, Hosoya NJ. Vitamin A transport in chicken plasma: isolation and characterization of retinol-binding protein (RBP), prealbumin (PA), and RBP-PA complex. J Lipid Res. 1975;16:200-210.

5. Rhodes MB, Bennett N, Feency RE. The flavoprotein-apoprotein system of egg white. J Bio chem. 1959;234(8):2054-2060.

6. Ostrowski W, Skarzynski B, Zak Z. Isolation and properties of flavoprotein from the egg yolk. Biochim Biophys Acta. 1962;59:515-517.
7. Karunakar RK, Pratap RMP, Veerababu N, et al. Purification and characterization of riboflavin carrier protein from egg white of South Indian spotted owlet (athene brama). International Journal of Applied Biology and Pharmaceutical Technology. 2012;3(4):2-6.

8. Madhukar RK, Prasad MSK. Purification and Characterization of riboflavin binding protein from (RfBP) Hen (Gallus gallus) DEAESepharose column chromatography. Int J Appl Biol. 2011;2(1):27-29.

9. Madhukar Rao K, Prasad MSK. Int J of Pharama Sci R. 2012;3:494 496.

10. Madhukar Rao K, Prasad MSK. Isolation and Purification of Riboflavin binding protein from Eagle egg yolk (Aquila hastate). Int J Appl Biology. 2012;3:351-354.

11. Bindu MR, Prasad MSK. Iner J of Plant and Animal Scie. 2012;2:5-9.

12. Adiga PR, Visweswariah SS, Karande AA, et al. Biochemical and immunological aspects of riboflavin carrier protein. $J$ Biosci. 1988;13(1):87-104.

13. Karande AA, Velu NK, Adiga PR. A monoclonal antibody recognizing the $\mathrm{C}$-terminal region of chicken egg white riboflavin carrier protein terminates early pregnancy in mice. Mol Immunol. 1991;28(4-5):471478 .

14. Naber EC, Cravens WW, Baumann Ca, et al. The effect of thiamine analogs on embryonic development and growth of the chick. J Nutr. 1954;54(4):579-591.

15. Coates ME. In Physiology and biochemistry of the domestic fowl. In: Bell J, Freeman BM, editors. USA: Academic Press; 1971. p. 1, 373.

16. Rhodes MB, Bennett N, Feency RE. The flavoprotein-apoprotein system of egg white. J Bio chem. 1959;234(8):2054-2060.

17. Maw AJG. Inherited Riboflavin Deficiency in Chicken Eggs. Poultry Sci. 1954;33(1):216-217.

18. Cowan JW, Boucher RU, Buss EG. Poultry Sci. 1964;45:538-541

19. Cowan JW, Boucher RU, Buss EG. Poultry Sci. 1966;45:538-41.

20. Winter WP, Buss EG, Clagett CO, et al. Comp Biochem Physiol. 1967;22(3):897-906.

21. Apweiler, et al. Fold Des. 1996;1(Suppl):3.

22. Gasteiger E, Gattiker A, Hoogland C, et al. ExPASy: The proteomics server for in-depth protein knowledge and analysis. Nucleic Acids Res. 2003;31(13):3784-3788.

23. Geourjon C, Deleage G. SOPMA: significant improvements in protein secondary structure prediction by consensus prediction from multiple alignments. Comput Appl Biosci. 1995;11(6):681-621. 
24. Pagni M, Ioannidis V, Cerutti L, et al. MyHits: improvements to an interactive resource for analyzing protein sequences. Nucleic Acids Res. 2007;35:W433-W437.

25. Nadhira NK, Madhukar RK, Srikanth CN, et al. Scholars Research Library. Annals of Biological Research. 2014;5(2):92-95.
26. Rajender G, Benajee G, Prasad MSK. Purification and characterization of riboflavin binding protein in egg white of peacock (Pavo cristatus). Cur Sci. 2007;93:24-25.

27. Maehashi K, Matano M, Nonaka M, et al. Riboflavin-binding protein is a novel bitter inhibitor. Chem Senses. 2008;33(1):57-63 